\title{
Organic fertilizer applications improve the growth of vegetable crops and chemical properties in the tailings deposition area at Timika, Papua, Indonesia
}

\author{
SARTJI TABERIMA ${ }^{1, \boldsymbol{\gamma}}$, SARASWATI PRABAWARDANI' ${ }^{2}$, ROBERTH SARWOM ${ }^{3}$, GRAHAM LYONS ${ }^{4}$ \\ ${ }^{1}$ Soil Department, Faculty of Agriculture, Universitas Papua. Jl. Gunung Salju, Amban, Manokwari 98314, West Papua, Indonesia. \\ remail: atji.taberima1@gmail.com \\ ${ }^{2}$ Agronomy Department, Faculty of Agriculture, Universitas Papua. Jl. Gunung Salju, Amban, Manokwari 98314, West Papua, Indonesia \\ ${ }^{3}$ Reclamation Division, Department of Environmental, PT Freeport Indonesia. Timika 99910, Papua, Indonesia \\ ${ }^{4}$ School of Agriculture, Food and Wine, Waite Campus, The University of Adelaide. PMB 1, Glen Osmond, SA 5064, Australia
}

Manuscript received: 10 August 2020. Revision accepted: 7 September 2020.

\begin{abstract}
Taberima S, Prabawardani S, Sarwom R, Lyons G. 2020. Organic fertilizer applications improve the growth of vegetable crops and chemical properties in the tailings deposition area at Timika, Papua, Indonesia. Nusantara Bioscience 12: 134-142. This study aimed to observe growth responses of selected vegetable crops grown in the media of inactive tailings, the available nutrients (macro and microelements) in fresh tailings before and after planting, as well as the metal uptake by plant tissues. Research was conducted using Randomized Block Design with three treatments of organic matter (chicken manure, cow manure, and compost of Salvinia natans) to observe the response on growth and yield of kangkong, red spinach, tomato, and chili. Based on the geochemical data, the ratio of ANC/MPA ranged from $3.81(0-20 \mathrm{~cm})$ to $4.60(20-40 \mathrm{~cm})$. There was no acid potential, with ANC ratio $>1.5 \mathrm{x}$ MPA, and this result was supported by soil $\mathrm{pH}$, which was alkaline in both depths of tailings media, ranging from $7.94(0-20 \mathrm{~cm})$ to $7.90(20-40 \mathrm{~cm})$. There was no significant effect on the chemical properties in the first period before and after planting for three months of planting period, except for the application with organic fertilizers. The best organic fertilizers applied in fresh tailings were chicken manure, followed by the compost of $S$. natans and cow manure. These organic fertilizers produced good growth and yield components of kangkong, red spinach, tomato, and chili. Meanwhile, the lowest growth and yield response of these crops was shown by control (without compost or manure). The level of metal uptake by all vegetables was low, suggesting that these vegetables are safe to be consumed.
\end{abstract}

Keywords: Acid Neutralizing Capacity, compost, Maximum Potential Acidity, vegetables, organic manures, tailings

\section{INTRODUCTION}

Tailings are the residue of mining material, after the separation of valuable substances such as copper, gold, and silver elements. Separation of these elements involves crushing the parent material into fine particles, and precious elements were separated by flotation technique at MP74, Timika, Papua. The total amount of tailings produced by PT Freeport Indonesia (PTFI) is app. 230,000 tons/day (PT. Freeport Indonesia 2007). These tailings are transported and deposited in the lowlands of Timika and confined in two levees, East Levee and West Levee, known as Modified Ajkwa Deposition Area (ModADA). The need to focus on reclamation in the Double Levee Area represents a significant opportunity to demonstrate PTFI's willingness to meet its environmental commitments early by enabling research for over thirty years in relation to the validity of potential approaches which can be applied to the ModADA as a whole (PT. Freeport Indonesia, 1997). There is an app. $113.076 \mathrm{~m} 2$ inactive-deposited tailing area since 1995 (20 years as inactive tailings) in the West part of DLA (Double Levee Area) MP21.5.

In line with sustainable development, the reclamation of tailings land is PTFI's priority for the use of the community around the mine area. However, there has been no reclamation activity yet, although grasses naturally grow well here. At the beginning of 2015, PT Freeport Indonesia under the Reclamation Division-Environmental Department, carried out an action plan for ten years in the DLA, by using the fresh tailings area to cultivate several horticultural crops (vegetables and fruits) with economic value. However, metal concentration in the tailings is the primary concern when food crops are cultivated in this area, as high concentrations of heavy metals in the environment can pose concerns for human health due to their persistence, carcinogenic and mutagenic effects (Turgut et al. 2004). Heavy metals found included several toxic metals in small amounts that can cause fatal poisoning. According to Gossel and Bricker (1984), there are five types of metals that are harmful to humans, i.e., arsenic (As), cadmium $(\mathrm{Cd})$, lead $(\mathrm{Pb})$, mercury $(\mathrm{Hg})$, and iron $(\mathrm{Fe})$. In addition, there are three less toxic metals, i.e., copper (Cu), selenium (Se), and zinc (Zn) (Darmono 2001). According to the Indonesia State Ministry of Population and Environment (1990) the toxicity of heavy metals can be grouped into (i) Highly toxic $(\mathrm{Hg}, \mathrm{Cd}, \mathrm{Pb}, \mathrm{Cu}$, and $\mathrm{Zn}$ ); (ii) moderately toxic $(\mathrm{Cr}, \mathrm{Ni}$, and $\mathrm{Co}$ ); (iii) low physical properties ( $\mathrm{Mn}$ and $\mathrm{Fe}$ ). 
The presence of heavy metals can cause pollution of underground water, which is toxic to plants, and soil microorganisms (California State Water Resources Control Board 2000). Furthermore, the uptake and accumulation of these metals in plants can cause adverse effects in terms of growth and biomass yield due to the impairment of natural processes such as photosynthesis, respiration, and nitrogen assimilation (Toppi and Gabbrielli 1999).

\section{MATERIALS AND METHODS}

The experiment was conducted from 2015 to 2016 in the fresh tailings at MP 21.5, Timika, Papua, Indonesia. The tailing particle size was medium to fine. Map of tailing deposition area at MP 21.5 is presented in Figure 1. The field experimental design was Randomized Block Design with three (3) replications. There were four (4) treatments of organic material application, i.e. (i) Chicken manure, (ii) Cow manure, (iii) Compost of Salvinia natans, and (iv) Control or no treatment, applied to several leaf and fruit vegetables namely kangkong, red spinach, tomato, and chili.

The sampling of tailing media before planting was taken at two depths: (i) $0-20 \mathrm{~cm}$ and (ii) $20-40 \mathrm{~cm}$ based on a regular systematic grid sampling method. Samples of plant tissues (fruit or leaf) were taken from representative samples of each seedbed per treatment of chicken manure, cow manure, compost of $S$. natans, and control.

Data were collected from the result of chemical analysis of fresh tailing before and after planting. Data on plant growth parameters were measured at vegetative and generative phases and from plant tissues analysis after harvest. The analysis of tailing media consisted of chemical and geochemical properties.
Samples of plant tissue after harvest were taken from stem and leaves of vegetables at 4-5 weeks after planting. Plant growth measurement was performed at two phases (Vegetative phase; consisted of stem diameter, leaf number, and plant height of leaf vegetables and Generative phase; consisted of numbers of fruit and fresh weight of harvested fruit and vegetables).

Data on plant growth and yield parameters were statistically analyzed using analysis of variance (ANOVA), and continued by Least Significant Difference (LSD test) if the treatment means are significantly different. The analysis of fertility status was conducted at the Laboratory of SEAMEO-BIOTROP, Bogor, Bogor. The analysis of metal uptake was conducted at the Timika Environment Laboratory (TEL). The chemical analysis data were obtained using the tabulation method. The criteria of chemical properties referred to BPT (2010), whereas the criteria of metal uptake from tailings media and plant tissues referred to Pais and Jones (1997).

\section{RESULTS AND DISCUSSION}

\section{Geochemical properties and the fertility status of fresh tailing prior to vegetable cultivation}

The geochemical properties of the fresh tailings at MP 21.5 before planting at two depths $(0-20 \mathrm{~cm}$ and $20-40 \mathrm{~cm})$ are presented in Table 1. Based on the analysis, ANC/MPA ratio at both depths ranged from 3.81 to $4.60(0-20 \mathrm{~cm}$; 20$40 \mathrm{~cm})$. The ANC/MPA ratio also showed no acid potential, in which ratio of ANC was 1.5 higher than MPA, as supported by $\mathrm{pH}$ value. The reaction of $\mathrm{pH}$ was alkaline in both samples of fresh tailings, which ranged from 7.94 $(0-20 \mathrm{~cm})$ to $7.90(20-40 \mathrm{~cm})$.

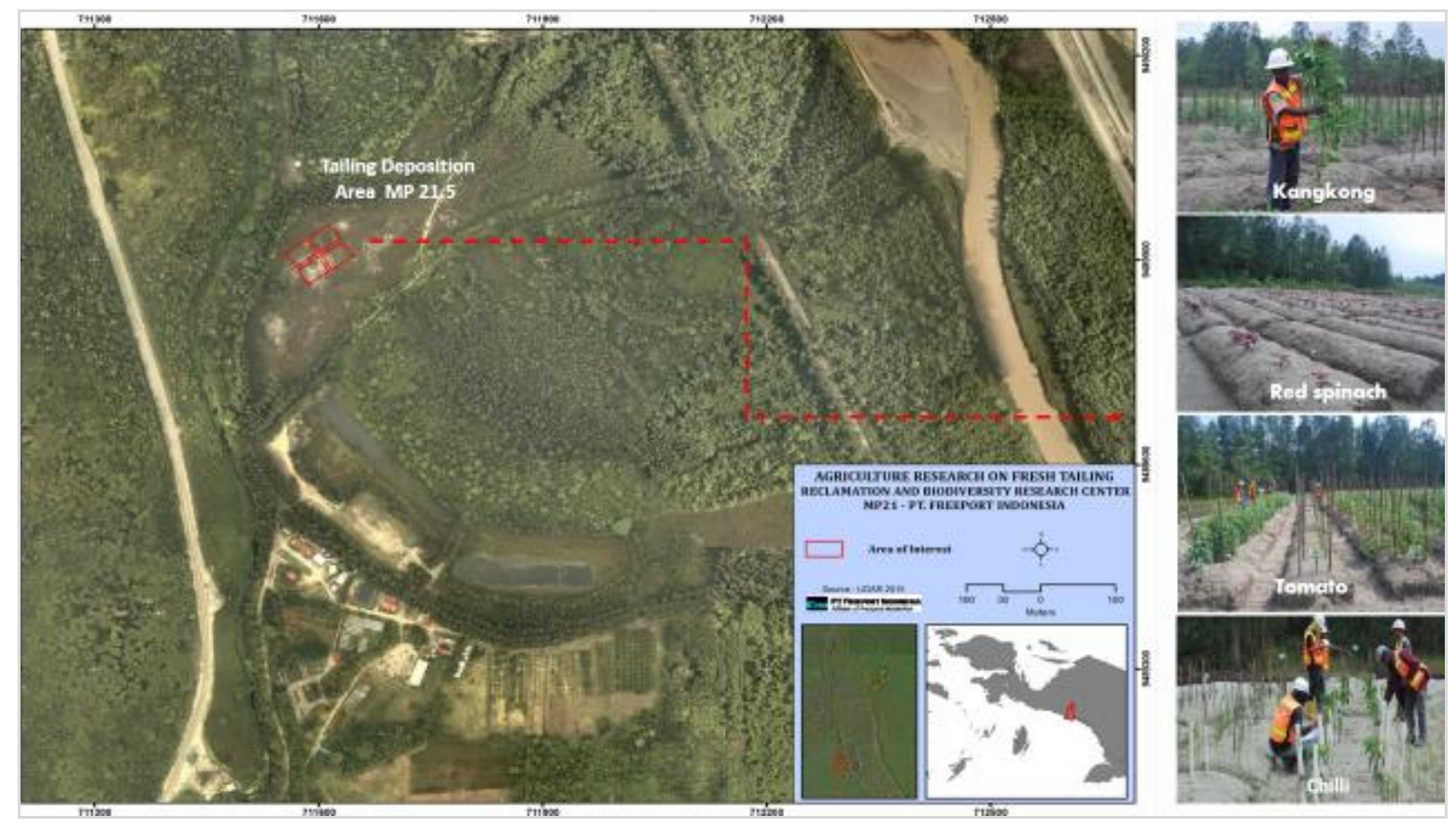

Figure 1. Map of vegetable crops in the Tailings Deposition Area at DLA-MP 21.5, Timika, Papua, Indonesia 
Tailings have different chemical characteristics when compared with natural soil derived from the parent rock. Tailings contain sulfide minerals, such as pyrite $\left(\mathrm{FeS}_{2}\right)$, chalcopyrite $\left(\mathrm{CuFeS}_{2}\right)$, covellite $(\mathrm{CuS})$, bornite $\left(\mathrm{Cu}_{5} \mathrm{FeS}_{4}\right)$, and diogenite $\left(\mathrm{Cu}_{2} \mathrm{~S}\right)$ (PT. Freeport Indonesia, 1997). Although copper $(\mathrm{Cu})$ has been removed in the processing of ore at MP 74, $\mathrm{Cu}$ and other micronutrients including $\mathrm{FeS}_{2}$ are still high in concentration. These metals can potentially create acidic conditions in the tailings when oxidized at DLA. To prevent acidification due to the sulfide oxidation, tailings have been limed into neutralizing capacity at 1,5 times from the maximum of potential acidity before entering to DLA (PT. Freeport Indonesia 2007). $\mathrm{CaO}$ and $\mathrm{CaCO}_{3}$ retain the $\mathrm{pH}$ of the tailings in the range of 7-8. According to Conesa et al. (2007), tailings with neutral $\mathrm{pH}$ seem to have fewer constraints to plant growth than acid tailings since the $\mathrm{pH}$ is more suitable for plant growth.

\section{The fertility status of fresh tailings prior to planting with vegetable crops}

Figure 2 shows the fertility status of tailings, which was very low in concentrations of essential macronutrients. The concentration of $\mathrm{C}$-org and $\mathrm{N}$ total were very low in both layers $(0-20 ; 20-40 \mathrm{~cm})$. The $\mathrm{pH}$ of tailings was alkaline. Therefore, the metal uptake generally tends to be lower in the plant tissue. The base cations of $\mathrm{Ca}$ and $\mathrm{K}$ were high, but $\mathrm{Mg}$ and $\mathrm{Na}$ were low. The base cations with the same oxidation number tend to compete in the soil solution. The value of CEC was very low because tailings have no structure, and are low in organic matter and clay. In consequence, there is no colloid from organic matter or clay, so the tailings capacity to hold nutrients or water becomes very low. The $\mathrm{pH}$ affects the solubility and availability of most nutrients. Plant availability of most metals is lower at high soil $\mathrm{pH}$. Total $\mathrm{N}$ and $\mathrm{C}$ organic were very low $(<0.01 \%$ and $<1 \%$, respectively) in the fresh tailings. To improve the fertility status of tailings, organic matter application would be beneficial in increasing CEC, $\mathrm{OC}$, and $\mathrm{N}$. In addition, organic matter may also increase the activity of microorganisms.

Table 1. Geochemical properties of fresh tailings in MP 21.5, Timika, Papua, Indonesia

\begin{tabular}{|c|c|c|c|}
\hline \multirow{2}{*}{ Parameter } & \multirow{2}{*}{ Unit } & \multicolumn{2}{|c|}{ Depth average $(\mathrm{cm})$} \\
\hline & & $0-20$ & $20-40$ \\
\hline $\mathrm{pH} \mathrm{H}{ }_{2} \mathrm{O}$ & & 7.94 & 7.90 \\
\hline $\mathrm{EC}_{2} \mathrm{O}$ & $\mu \mathrm{S} / \mathrm{cm}$ & 1426.67 & 1633.33 \\
\hline ANC & $\mathrm{kg} \mathrm{H}_{2} \mathrm{SO}_{4} /$ ton & 263.67 & 252.67 \\
\hline Total Sulfur (S) & $\%$ & 2.92 & 2.86 \\
\hline $\mathrm{NAG} \mathrm{pH}$ & & 8.80 & 8.50 \\
\hline NAG pH 4.5 & $\mathrm{~kg} \mathrm{H}_{2} \mathrm{SO}_{4} /$ ton & 0 & 0 \\
\hline NAG pH 7.0 & $\mathrm{~kg} \mathrm{H}_{2} \mathrm{SO}_{4} / \mathrm{ton}$ & 0 & 0 \\
\hline MPA & & 89.352 & 87.52 \\
\hline NAPP & & -174.31 & -165.15 \\
\hline ANC/MPA & & 3.81 & 4.60 \\
\hline
\end{tabular}

Notes: Data were released by Timika Environment Laboratory (TEL), 2015. EC: electrical conductivity; ANC: acid-neutralizing capacity; MPA: maximum potential acidity

The Fertility Status prior to planting at MP 21.5

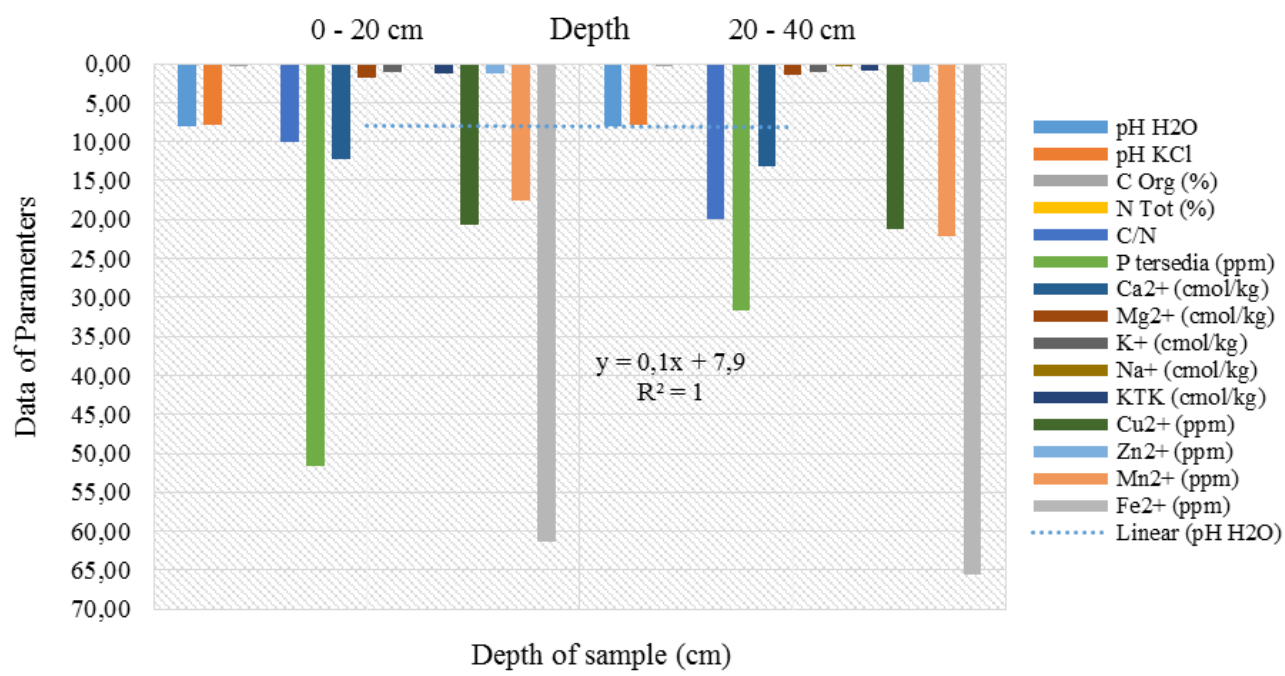

Figure 2. The Soil Fertility Status prior to planting at MP 21, Timika, Papua, Indonesia 
The concentrations of essential micronutrients $(\mathrm{Cu}, \mathrm{Fe}$, $\mathrm{Mn}$ ) were high, while $\mathrm{Zn}$ was moderate (BPT 2010). On the other hand, the concentration of one macronutrient, phosphorus (P) was very high. It was suspected that the tailings contain $\mathrm{P}$ from the parent material, or it may be derived from a reagent of $\mathrm{CaO}$, which was added in the flotation process at MP 74. The macro and micronutrient contents (including metals) on the fresh tailing tend to be low in $\mathrm{N}, \mathrm{K}$, and C-org concentration, but high in $\mathrm{Fe}, \mathrm{Mn}$, $\mathrm{Cu}$, and $\mathrm{Zn}$ concentration. The availability of $\mathrm{Fe}, \mathrm{Mn}$, and $\mathrm{Cu}$ were high in concentration because these tailings hold high amounts of these elements. The concentration of $\mathrm{Cu}$ ranges from 9.1-20.7 ppm; $\mathrm{Mn}$ ranges from 14.2-23.9 ppm; $\mathrm{Fe}$ ranges from 49.2-88.1 ppm, and varies between the depth of two layers. Basically, higher $\mathrm{Cu}$ availability is the result of low $\mathrm{pH}$ and the impact of sulfide oxidation.

Generally, the total $\mathrm{S}$ in the soil ranged from 30 to $1000 \mathrm{ppm}$ with the mean value approximately $700 \mathrm{ppm}$ $(0.07 \%)$ (Lindsay 1979). Tabatabai et al. (1988) stated that total $\mathrm{S}$ in most of the soil ranged from $20 \mathrm{ppm}$ in sandy soil to $600 \mathrm{ppm}$ in solid soil, while most soil contains $\mathrm{S}$ between 100 and $500 \mathrm{ppm}$. At the DLA, total S is relatively high because the parent material from Grasberg contains the group of sulfide minerals. MacDonald and Arnold (1994) reported that total S content in the parent material of Grasberg mining was $1.59 \%$. Related to the plant requirement, $\mathrm{S}$ is an essential element in the formation of the two types of amino acid (Cysteine and Methionine); Mn functions with enzyme systems involved in the breakdown of carbohydrates, and nitrogen metabolism; Zn is part of the enzyme systems which regulate plant growth; whereas, $\mathrm{Fe}$ and $\mathrm{Mg}$ are needed for leaf green pigment or chlorophyll (Devlin and Whitam 1983), but these elements were present in low concentrations at fresh tilling.

\section{Growth of vegetables in the fresh tailings}

Figure 3.A shows the vegetative phase of kangkong at 1-4 WAP. The application of organic fertilizers produced more kangkong leaves during the vegetative phase (1-5 WAP). The application of cow manure to the fresh tailing media produced taller plants and more leaves than that of chicken manure and composted S. natans. The lowest growth was produced by control (without organic manure). Stem diameter, leaf number, and plant height of red spinach collected at 1-4 WAP are presented in Figure 3.B. The application of chicken manure and compost of $S$. natans produced the highest growth parameters during the vegetative phase, while the lowest growth was shown by cow manure and control treatments.

\section{Leaf vegetables: kangkong and red spinach}

The application of cow manure in the fresh tailing produced significantly the highest fresh weight (596.67 g) of kangkong at 5 WAP, followed by the application of chicken manure which produced $553.33 \mathrm{~g}$ (Figure 4.A). Meanwhile, the application of $S$. natans compost and control treatments resulted in the lowest fresh weight at harvest. However, chicken manure produced significantly the highest fresh weight of red spinach $(59.17 \mathrm{~g})$, followed by S. natans compost $51.53 \mathrm{~g}$ (Figure 4.B). Figure 5 shows growth and yield of kangkong and red spinach.

\section{Fruit vegetables: tomato and chili}

Figure 6.A shows the vegetative phase of tomato at 1-9 WAP. The application of chicken manure in the tailings produced the highest plant height, from 3 to 9 WAP, followed by cow manure and compost of $S$. natans. Whereas, control treatment produced the lowest plant height. Figure 6.B shows the vegetative components of chili at 2-10 WAP. Chicken manure treatment produced the highest vegetative growth components, followed by cow manure and compost of $S$. natans. However, the lowest vegetative growth was produced by control treatment. There was no significant difference in stem diameter among the organic fertilizer treatments, while the lowest stem diameter was produced by the control treatment.

Figure 7.A shows the average fruit number and fresh weight of tomato. Fresh tailing applied with chicken manure produced the highest fruit number of 36 and the weight of $702.73 \mathrm{~g}(0.703 \mathrm{~kg})$, followed by the compost of $S$. natans with an average fruit number of 28 and the weight of $656.84 \mathrm{~g}(0.657 \mathrm{~kg})$ and cow manure with fruit number of 25 and the fruit weight of $527.93 \mathrm{~g}(0.528 \mathrm{~kg})$. The lowest crop growth was indicated by control (without organic fertilizers). Without organic fertilizers, Tomato plant produced 1 fruit number and the fruit weight was $10.83 \mathrm{~g}(0.0108 \mathrm{~kg})$. The compost worked well for producing red spinach (Figure 4.B) and tomatoes, but not as good as the manures for producing kangkong (Figure 4.A) or chili.

Figure 7.B shows the application of cow manure to the tailing produced the highest chili fruit number (16) and significant fruit weight $46.61 \mathrm{~g}(0.047 \mathrm{~kg})$, followed by chicken manure treatment with 15 fruits which weigh 41.43 $\mathrm{g}$ or $0.041 \mathrm{~kg}$. The compost of $S$. natans and control treatments produced 7 and 6 fruit which weigh $17.21 \mathrm{~g}$ and $14.40 \mathrm{~g}$, respectively. The application of cow and chicken manure significantly produced the highest number of fruit and fresh weight of chili. However, compost of S. natans and control produced the lowest number of fruit and fresh weight of chili. According to Ainun et al. (2003), the application of organic material from chicken manure contributed positively to the growth of Chinese cabbage and tomato. Organic matter from chicken manure is able to produce complex metalloids and increase plant growth (Ainun et al. 2003). Compost applied in the tailing media may improve the development of roots and microbial activity on the soil (Hilwan 2015). The activity of microbes that are symbiotic with plants will help to produce the compounds (e.g. auxin and vitamins) for rooting development and plant growth (Hilwan 2015). Figure 8 shows growth and yield of tomato and chili. 


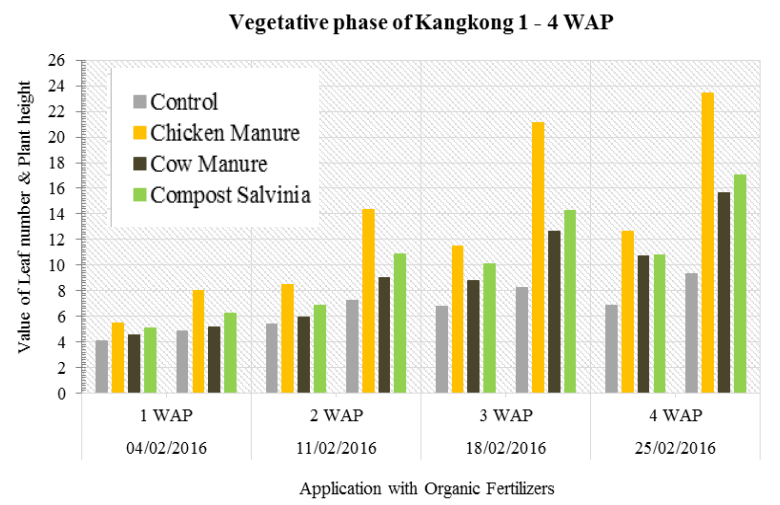

A

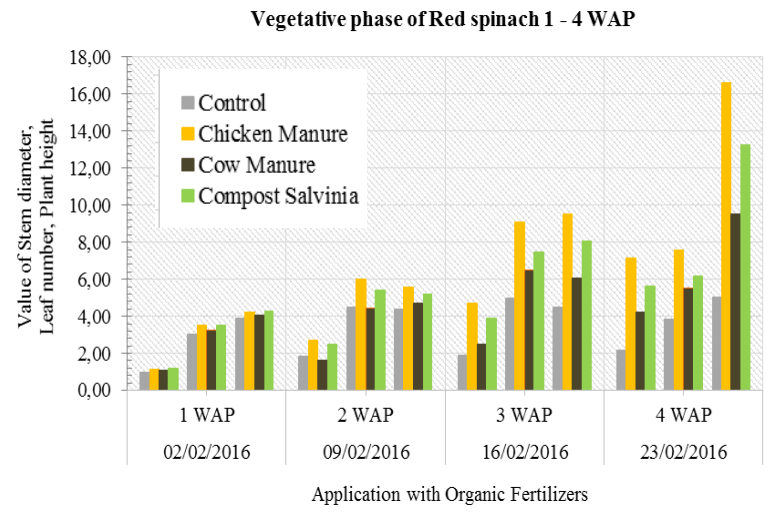

B

Figure 3. The vegetative phase of kangkong (A) and red spinach (B)

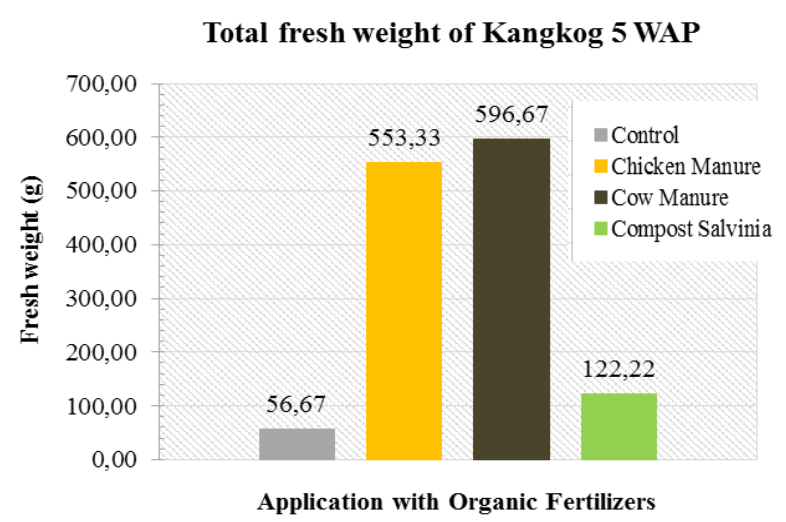

A

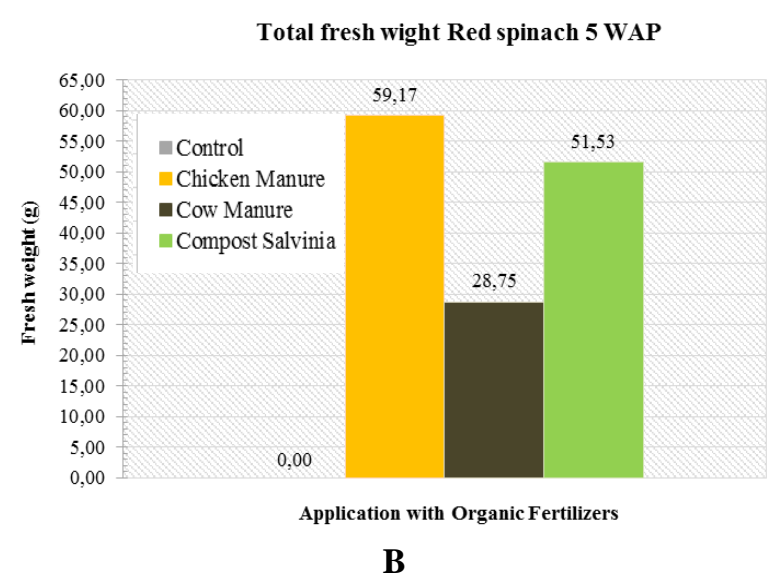

Figure 4. Total fresh weight of kangkong (A) and red spinach (B)
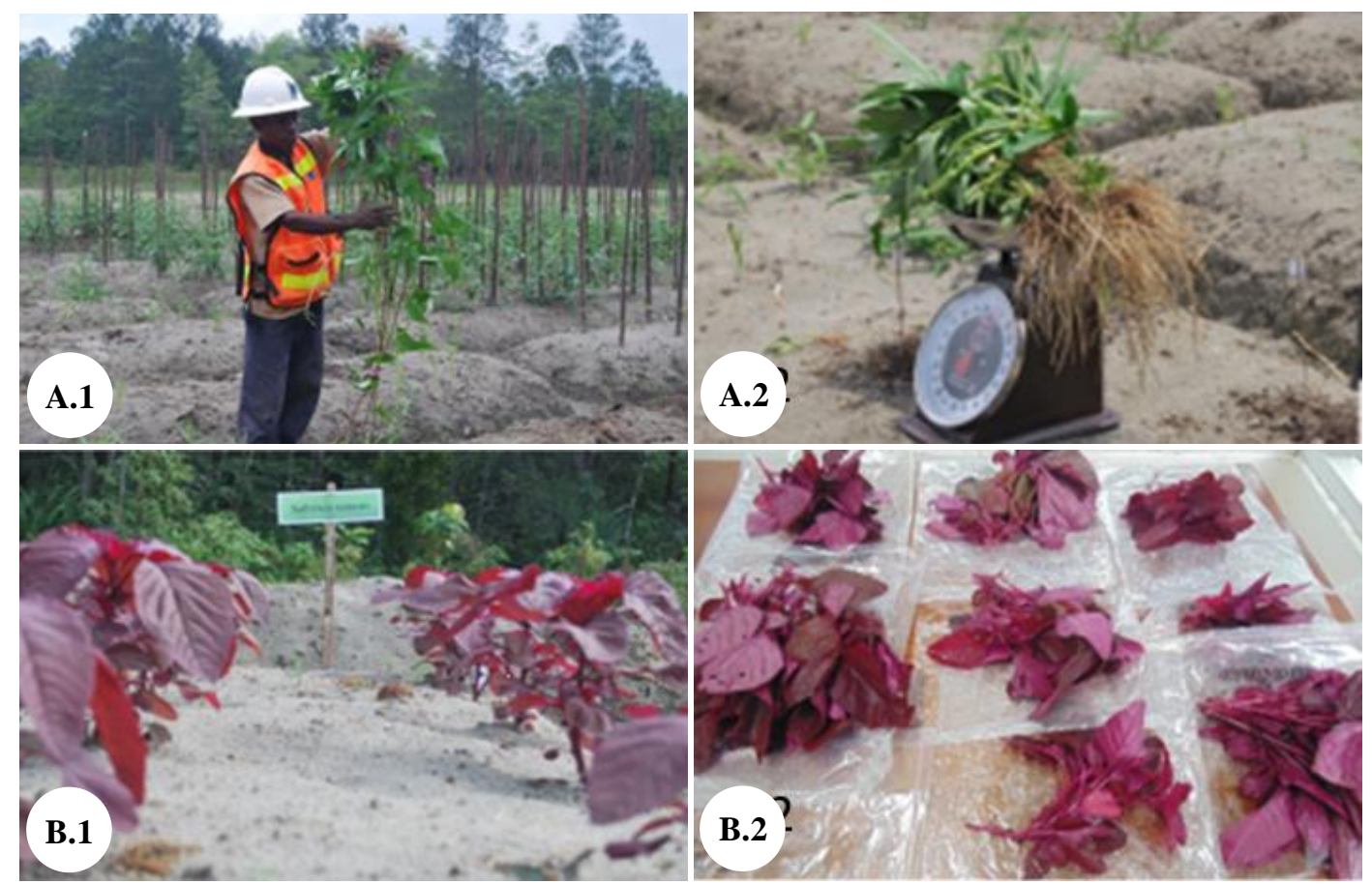

Figure 5. Growth and yield of kangkong (A.1 and A.2) and red spinach (B.1 and B.2) at MP 21.5, Timika, Papua, Indonesia 
Period I : Vegetative phase of Tomato, 1 - 9 WAP

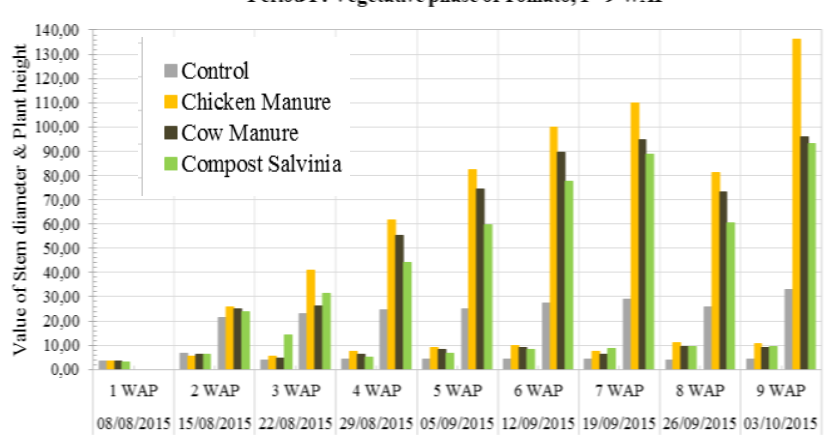

Measuring at WAP (week after planting)

A

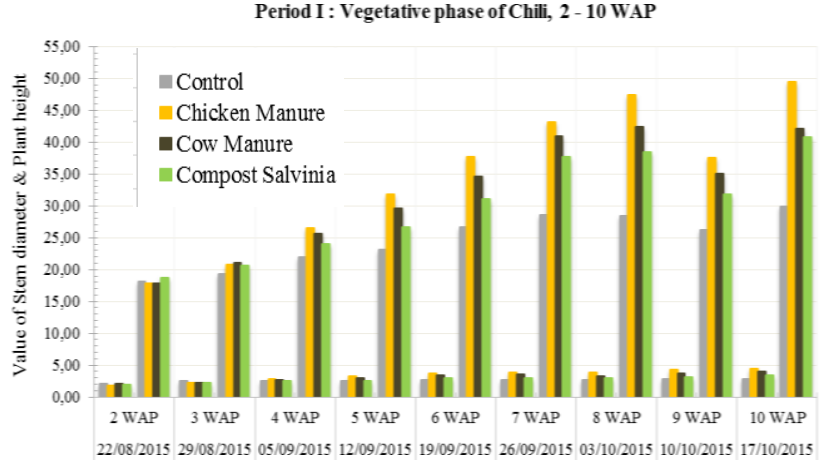

Measuring at WAP(week after planting)

B

Figure 6. The vegetative phase of tomato 1-9 weeks after planting (A) and chili 2-10 week after planting (B)

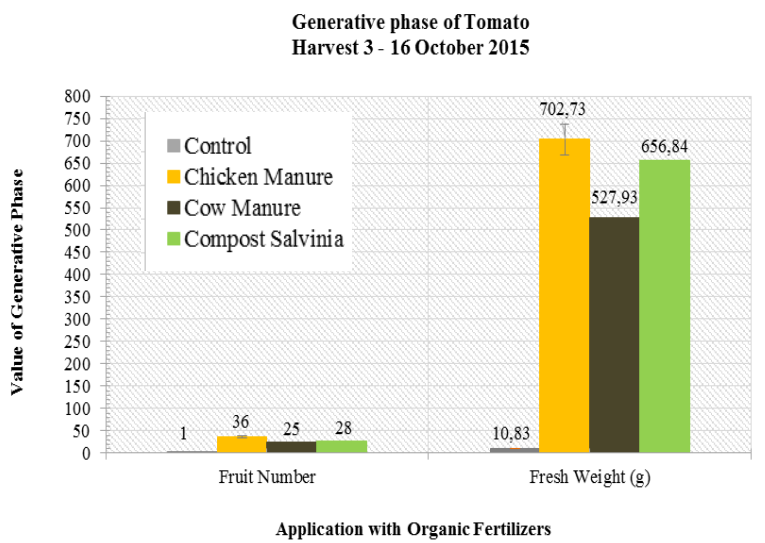

A

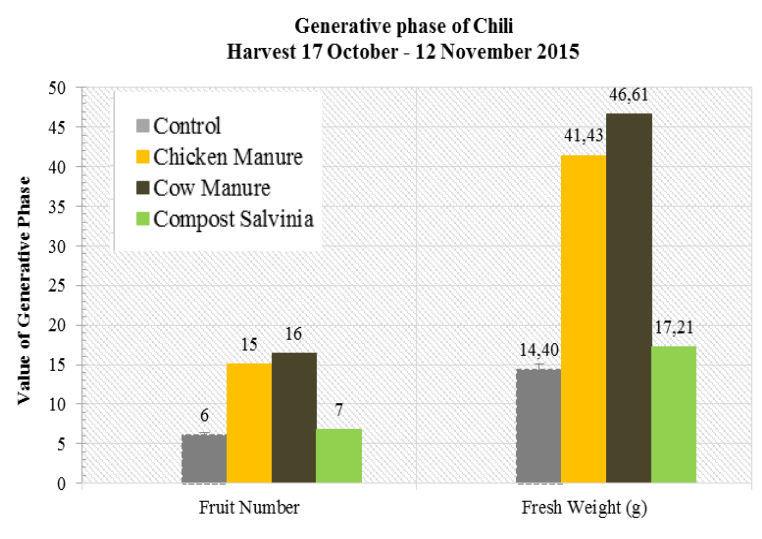

Application with Organic Fertilizers

B

Figure 7. The harvest time of tomato at $10 \mathrm{WAP}$ (A) and chili at $12 \mathrm{WAP}(\mathrm{B})$, Timika, Papua, Indonesia
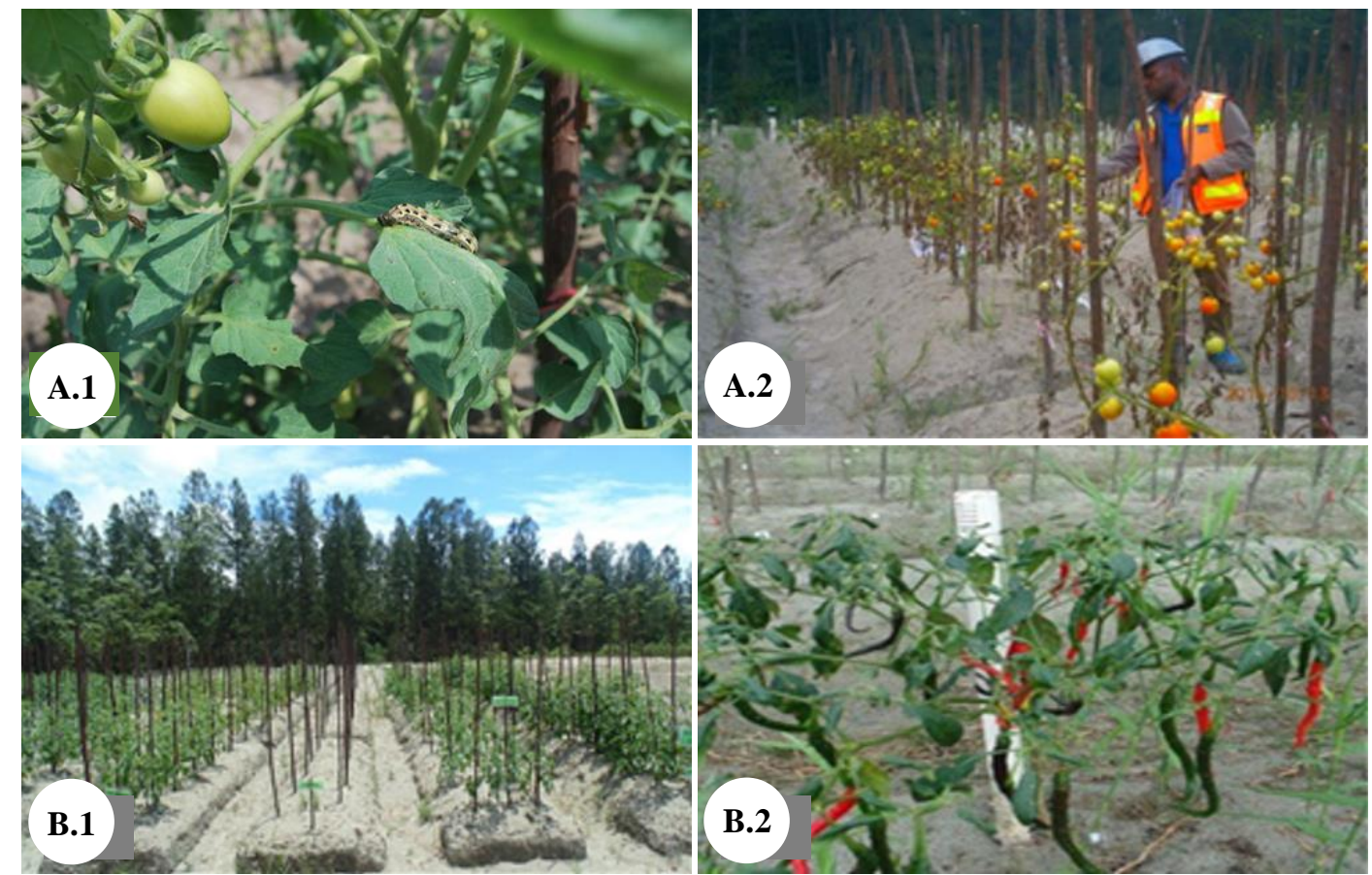

Figure 8. Growth and yield of tomato (A.1 and A.2) and chili (B.1 and B.2) at MP 21.5, Timika, Papua, Indonesia 


\section{Leaf vegetables: kangkong and red spinach}

The application of organic fertilizers to the fresh tailings, tends to affect the chemical properties of the fresh tailings, i.e., $\mathrm{pH}, \mathrm{Ca}$, and micronutrients of $\mathrm{Fe}, \mathrm{Mn}, \mathrm{Cu}$, and $\mathrm{Zn}$. However, the concentration of the micronutrients did not appear strong. The concentration of metal uptake (Fe, $\mathrm{Mn}, \mathrm{Cu}$ ) in stem and leaf of kangkong was higher with the compost of $S$. natans and also control. However, the metal uptake concentration by red spinach was higher in $\mathrm{Fe}, \mathrm{Mn}$, $\mathrm{Cu}$, and $\mathrm{Zn}$ without organic fertilizers. The organic fertilizers contain humic compounds which are the final result of plant material decomposition. This compound is an amorphous material, colloid, yellow to dark brown, and has a high molecular weight. The humic compounds also play a role in the forming of complex bonds with metals.
The formation of complexes with metals affects reactivity and toxicity (Matagi et al. 1998).

\section{Fruit vegetables: tomato and chili}

Figures 6 and 7 show that tomato fruits could not be produced without the application of organic matter in the fresh tailings. However, the metal uptake concentration of tomato and chili fruits were low in manure or compost treatments. The concentration of micronutrients $(\mathrm{Fe}, \mathrm{Mn}$, $\mathrm{Cu}, \mathrm{Zn}$ ) and also other elements were low in tomato and chili. The application of organic matter in the fresh tailings was very useful for plant growth for both the vegetative growth and generative phases.

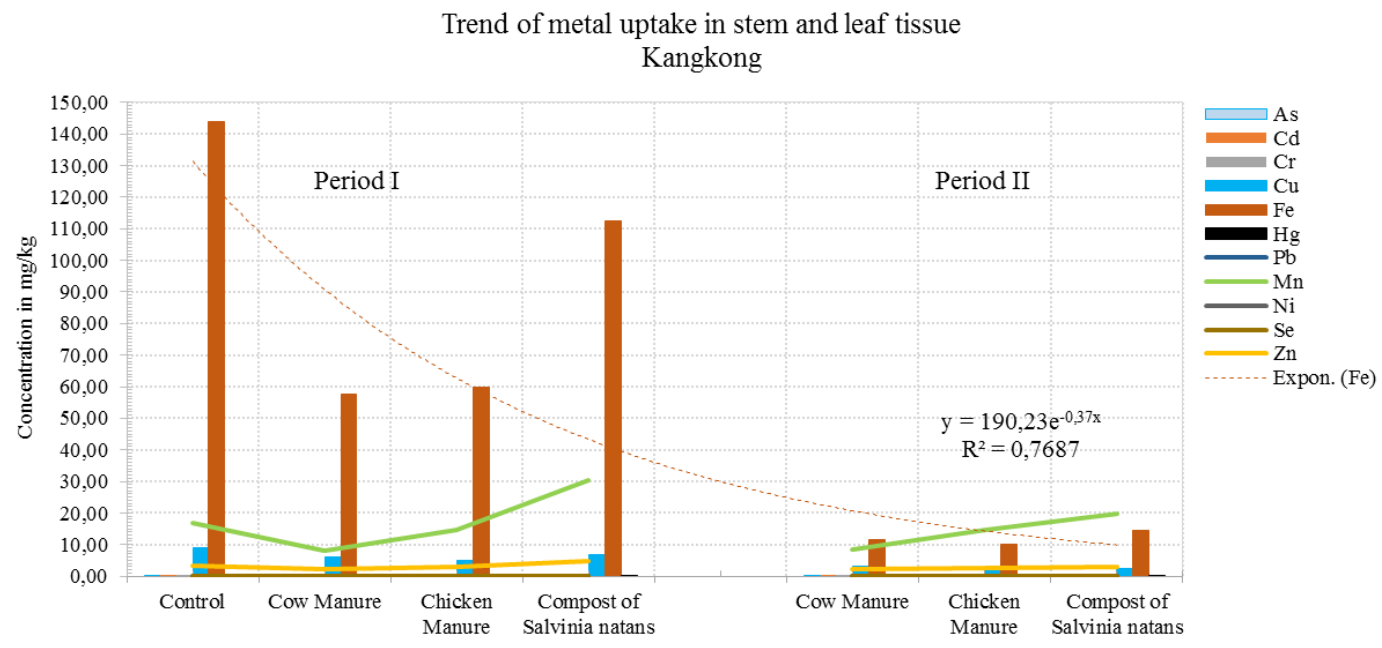

Figure 9. Trend of metal uptake within two periods of kangkong growth

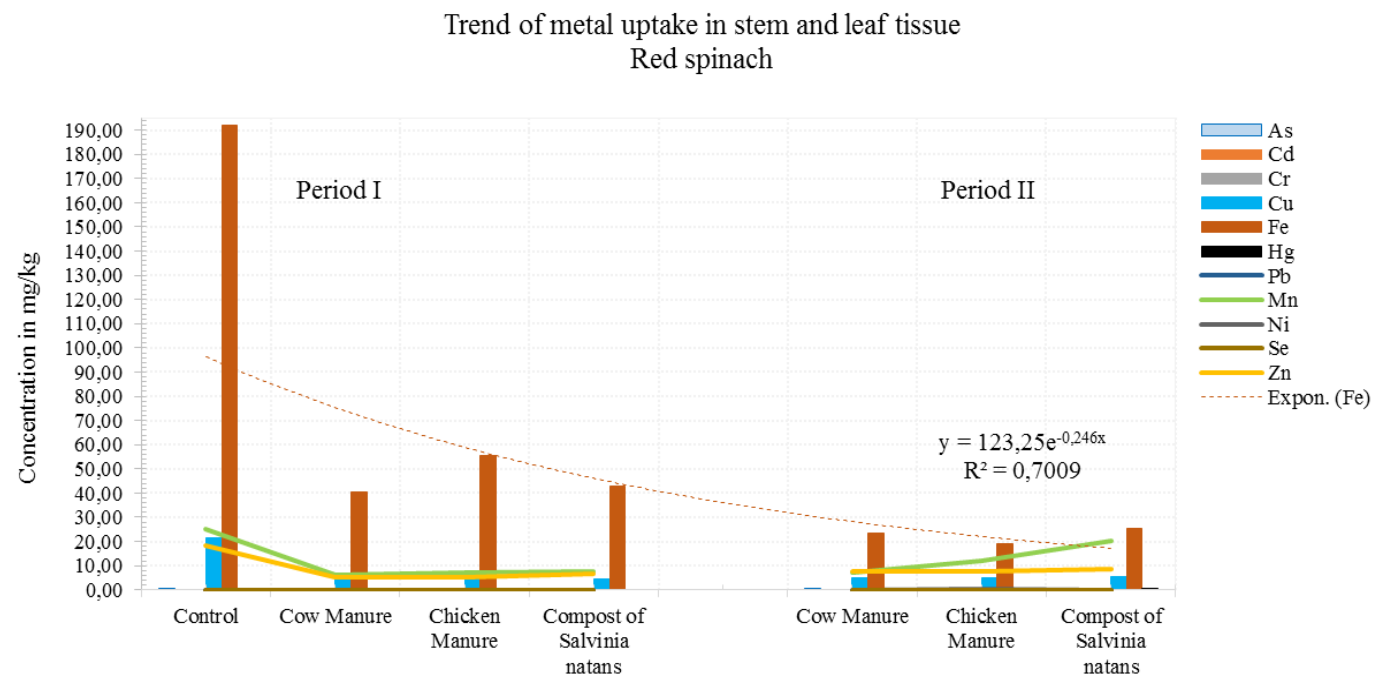

Figure 10. Trend of metal uptake within two periods of the red spinach growth 


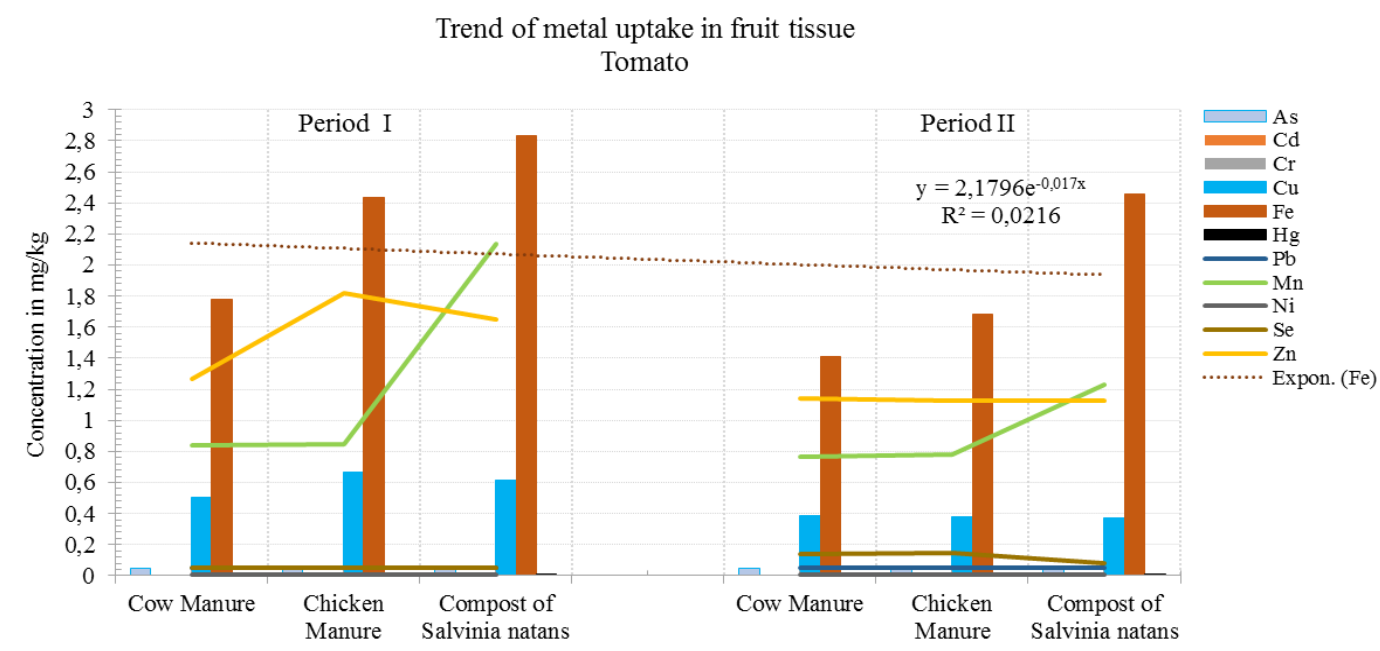

Figure 11. Trend of metal uptake within two periods of tomato growth

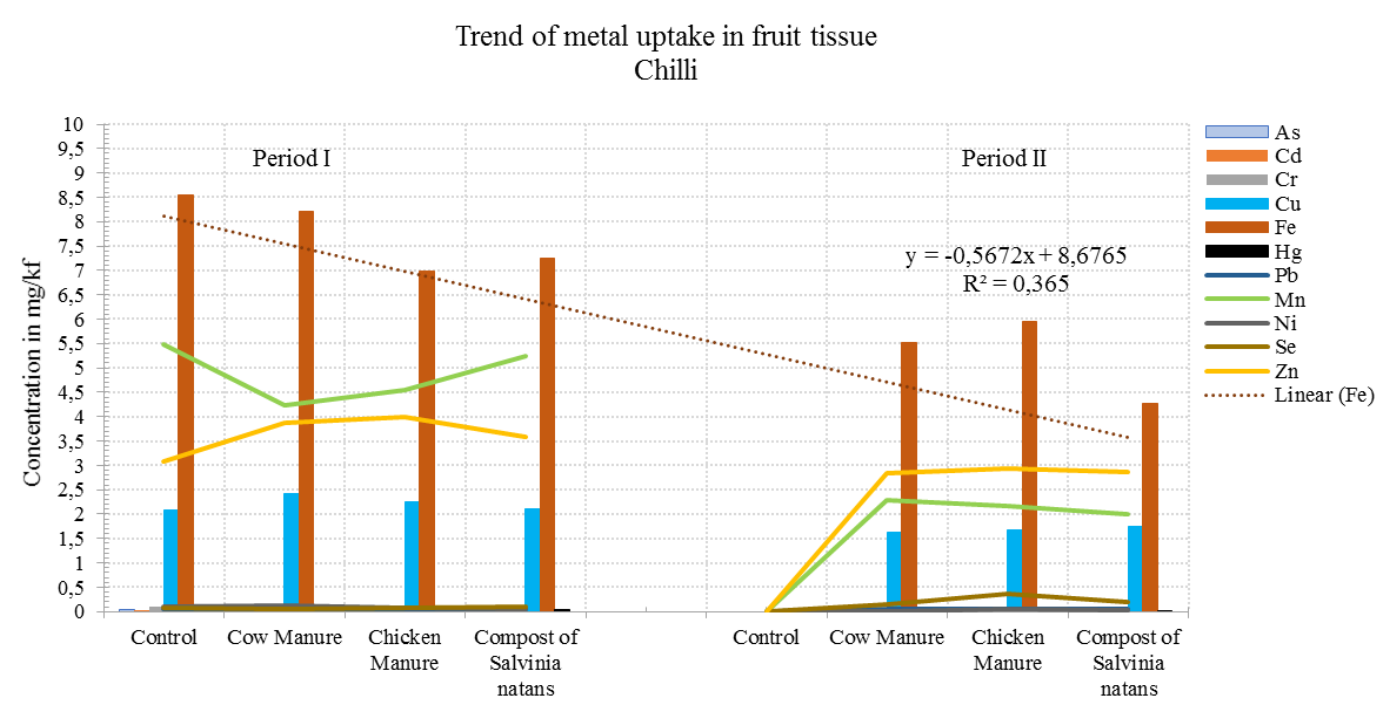

Figure 12. Trend of metal uptake within two periods of chili growth

In conclusion, organic matter can improve the chemical properties of the tailings as a planting medium. Application of organic fertilizers to the tailings produced better growth and higher yield of kangkong, red spinach, tomato, and chili than that of application without organic fertilizer. cow manure applied to the tailing media produced taller plants, higher leaf number, and greater fresh weight of kangkong than in the tailings treated with chicken manure and $S$. natans. On the other hand, the growth and yield of red spinach on the tailing media applied with chicken manure and compost of $S$. natans was better than that applied with cow manure and control treatments. The application of chicken manure also produced higher fruit number and fruit weight of tomato and chili. The level of metal uptake (As, $\mathrm{Cd}, \mathrm{Hg}, \mathrm{Pb}, \mathrm{Cr}, \mathrm{Hg}, \mathrm{Pb}, \mathrm{Mn}, \mathrm{Ni}$. Se, $\mathrm{Zn}$ ) by all vegetables was low, suggest that these vegetables are safe to be consumed.

\section{ACKNOWLEDGEMENTS}

As the research was supported by the Environmental Department of PTFI, Timika, Papua, Indonesia, the authors would like to thank the Division of Reclamation and Biodiversity MP 21, Timika. Also, thanks to Andi Muchsia, Gesang Setyadi, Barnabas Murib, Tumpal Sinaga, Nanang Amtono and the crews (Jimpul Kandau, Tonci Sroyer, Yance, Aprina Wahyuningtyas, Helena Maynase, Novanti Pusung, Novita Imbiri), and S. White for great support.

\section{REFERENCES}

Ainun N, Aiyen, Samudin S. 2003. Incorporating organic matter into gold tailing and its impact on growth and mercury $(\mathrm{Hg})$ uptake by Chinese 
cabbage (Brassica parachinensis L.) and tomato (Lycopersicum esculentum Mill.). e-J. Agrotekbis 1 (5): 435-442.

Balai Penelitian Tanah (BPT). 2010. Analisis Kimia Tanah, Tanaman, Air dan Pupuk. Badan Penelitian dan Pengembangan Pertanian, Departemen Pertanian. Bogor. [Indonesian]

California State Water Resources Control Board. 2000. Risks and Benefits. California Environmental Protection Agency.

Conesa HM, Schulin R, Nowack B. 2007. A Laboratory study on revegetation and metal uptake in native plant species from neutral mine tailings. Water Air Soil Pollut 183: 201-212. DOI 10.1007/s11270-007-9369-1.

Darmono. 2001. Lingkungan Hidup dan Pencemaran: Hubungannya dengan toksikologi senyawa logam. Universitas Indonesia. Jakarta. [Indonesian]

Devlin RM, Witham FH. 1983. Plant physiology. 4th ed. Willard Grant Press, Boston.

Gossel A, Bricker T, Douglas J. 1984. Principles of Clinical Toxicology. Publisher New York: Raven Press. 357 pages.

Hilwan I. 2015. Respon pertumbuhan tiga jenis tanaman pada media tailing bekas penambangan pasir kuarsa di Kabupaten Belitung Timur. Jurnal Silvikultur Tropika. 6 (2): 126-131. [Indonesian]

Pais I, Jones BJ Jr. 1997. The Handbook of Trace Elements. St. Lucie Press, Boca Raton, Florida

Lindsay WL. 1979. Chemical Equilibria in Soils. A Wiley Interscience Publication. John Wiley \& Sons, New York.

MacDonald GD, Arnold LC. 1994. Geological and geochemical zoning of the Grasberg Igneous Complex, Irian Jaya. J Geochem Exp 50: 143.
Matagi SV, Swai D, Mugabe R. 1998. Heavy metal removal mechanisms in Wetlands. Afr J Trop Hidrobiol Fish. 8: 23-35.

PT. Freeport Indonesia. 2007. Laporan Pelaksanaan Pengelolaan dan Pemantauan Lingkungan. Triwulan 1 Tahun 2007. PT Freeport Indonesia. Jakarta. [Indonesian]

PT. Freeport Indonesia. 1998. Rencana Tahunan Lima Tahun Pertama (1999-2003). Reklamasi Daerah Pengendapan Tailing PT. Freeport Indonesia. [Indonesian]

PT. Freeport Indonesia. 1997. Studi Analisis Dampak Lingkungan AMDAL Regional. Rencana Perluasan Kegiatan Penambangan Tembaga dan Emas serta Kegiatan Pendukungnya hingga Kapasitas Maksimum 300.000 ton bijih/hari di Kabupaten Mimika, Propinsi Irian Jaya. Laporan Utama PT Freeport Indonesia. Jakarta. [Indonesian]

Tabatai MA, Basta NT, Pirela HJ. 1988. Determination of total sulfur in soil dan plant materials by ion chromatography. Commun Soil Sci Plant Anal. 19:1701-1714.

Taberima S, Sarwom R. 2016. Status of macro and micronutrients from deposited tailings in reclamation area, PT Freeport Indonesia, Timika. J Degrad Mining Lands Manag 3 (3): 565-576.

Turgut C, Pepe MK, Cutright TJ. 2004. The effect of EDTA and citric acid on phytoremediation of $\mathrm{Cd}, \mathrm{Cr}$ and $\mathrm{Ni}$ from soil using Helianthus annuus. Environ Pollut. 131: 147-154.

Toppi SL, Gabbrielli R. 1999. Response to cadmium in higher plants. Environ Exp Bot 41: 105-130. 